Available online on 15.05.2020 at http://jddtonline.info
Open Access to Pharmaceutical and Medical Research
(c) 2011-18, publisher and licensee JDDT, This is an Open Access article which permits
unrestricted non-commercial use, provided the original work is properly cited

Open@ Access

Research Article

\title{
Antihyperglycemic activity of total extract and fractions of Anogeissus leiocarpus
}

\author{
Enam Aku Motto*, Povi Lawson-Evi, Yendube Kantati, Kwashie Eklu-Gadegbeku, Kodjo Aklikokou, \\ Messanvi Gbeassor
}

Laboratory of Physiology / Pharmacology. Faculty of Sciences, University of Lome - TOGO. BP 1515

\begin{abstract}
Anogeissus leiocarpus (Combretaceae) is a medicinal plant used by traditional practitioners to treat people living with diabetes mellitus in Togo. The objective of this work was to evaluate the hypoglycemic activity of the plant. The hydroalcoholic extract and fractions of $A$. leiocarpus roots was evaluated on hyperglycemic mice by oral glucose tolerance test (OGTT) and on normoglycemic mice. The effect of the total extract and fractions was also measured on the adsorption and absorption of glucose respectively in vitro and ex vivo. At 30 minutes after glucose overload, the total extract and all fractions (supernatant and pellet) significantly $(\mathrm{p}<0.0001)$ reduced hyperglycemia compared to controls. However, this reduction in hyperglycemia was greater in mice treated with the supernatant fraction at $100 \mathrm{mg}^{\mathrm{kg}} \mathrm{kg}^{-1} \mathrm{during} 180 \mathrm{minutes}$ ( $\mathrm{p}<0.01$ ). In our conditions, the extract at the $500 \mathrm{mg} \cdot \mathrm{kg}^{-1}$ of the total extract in normoglycemic mice did not significantly decrease ( $\mathrm{p}>0.05$ ) basal blood glucose levels compared to controls. In vitro, the extract and fractions of $A$. leiocarpus adsorbed glucose and inhibited glucose intestinal absorption ex vivo. The results of this study support the use of $A$. leiocarpus as an antidiabetic plant.
\end{abstract}

Keywords: Anogeissus leiocarpus- fractions- antihyperglycemic- adsorption - absorption.

Article Info: Received 10 March 2020; Review Completed 17 April 2020; $\quad$ Accepted 24 April 2020; Available online 15 May 2020

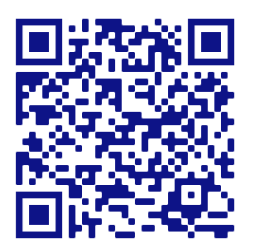

Cite this article as:

Motto EA, Lawson-Evi P, Kantati Y, Eklu-Gadegbeku K, Aklikokou K, Gbeassor M, Antihyperglycemic activity of total extract and fractions of Anogeissus leiocarpus, Journal of Drug Delivery and Therapeutics. 2020; 10(3):107-113

http://dx.doi.org/10.22270/jddt.v10i3.4078

MOTTO Aku Enam, Laboratory of Physiology/Pharmacology, Faculty of Sciences, University of Lome (TOGO)

\section{INTRODUCTION}

Diabetes is a chronic disease, with hallmark pathology of hyperglycemia, which is clinically represented by fasting blood glucose greater than $7.0 \mathrm{mM}$ and 2 hours glucose level greater than $11.1 \mathrm{mM}$ after glucose tolerance test. In diabetics, chronic hyperglycemia, source of oxidative stress remains a very critical condition because of its nature to generate serious complications as retinopathy, nephropathy, neuropathy and cardiovascular disease 1.

Globally, diabetes is the major health issue that has reached alarming levels ${ }^{2}$. For the management of diabetes, dietary changes and oral antihyperglycemic drugs have been investigated to stimulate insulin secretion, to decrease glucose absorption from the gut, or suppress endogenous glucose by increasing glucose peripherical utilization 3 . Unfortunately, some of them have been failed due to longerterm adverse side effects ${ }^{4}$. An alternative and perhaps underutilized source of new antidiabetic compounds is plants because of their lack of major side effects.

Anogeissus leiocarpus (Guill and Perr) of the family of Combretaceae, is a plant which widely spread throughout the tropical and subtropical areas. Previous studies on roots, stem barks of the plant, revealed antimicrobial, antiproliferative, antioxidant and hepatoprotective properties 5,6,7. The leaves of $A$. leiocarpus have been scientifically reported to decrease blood glucose effects in alloxan-induced diabetic rats ${ }^{8}$. Roots of this plant were also reported by Kpodar et al to be used traditionally to treat people living with diabetes in Togo ${ }^{9}$. However, there is still no scientific report on its antidiabetic property up to now. Consequently, this present investigation was carried out to evaluate the hypoglycemic of the roots of $A$. leiocarpus

\section{MATERIALS AND METHODS}

\section{Plant material}

Roots of Anogeissus leiocarpus were harvested in Tsévié, Zio (TOGO) in the month of July 2018. A voucher specimen was identified and was deposited in the herbarium of Laboratory of Botany and Plant Ecology under the number TOGO 15483.

Roots of Anogeissus leiocarpus were cleaned out with water, cut into small pieces, dried at the Animal Physiology laboratory at $22^{\circ} \mathrm{C}$.

\section{Animals}

ICR mice $(25 \pm 4 \mathrm{~g})$ and S.D rats $(160 \pm 165 \mathrm{~g})$ were housed in 
standard environmental conditions (temperature $24-25^{\circ} \mathrm{C}$, relative humidity and a 12t/12 h light-dark cycle) and fed with standard rat diet and water ad libitum. The animals were deprived of both food and water during the experiment. Principles of laboratory animal care as described in institutional guidelines and ethics of Laboratory of Physiology/Pharmacology of University of Lome-Togo (ref: 001/2012/ CB-FDS-UL) were followed.

\section{Extraction}

Roots of Anogeissus leiocarpus (400g) were extracted in water/ethanol (5:5) for 72 hours. The crude extract was filtered on Whatman paper and evaporated in vacuum at $45^{\circ} \mathrm{C}$ using a rotary evaporator (Buchi R120). The yield of the dry extract was $5.68 \%$.

About 30g of hydroethanolic extract obtained was suspended in frozen ethanol 75\% within 24 hours. Supernatant was separated from pellet by centrifugation at 2500 trs.min $^{-1}$ and evaporated in vacuum at $45^{\circ} \mathrm{C}$ using a rotary evaporator. Pellet was then concentrated to dryness 10.

\section{Effects of total extract of Anogeissus leiocarpus and fractions on oral glucose tolerance test}

Hyperglycemia was induced in fasted mice ( 9 hours) by glucose gavage (4g.kg-1 body weight) at a rate of $5 \mathrm{ml} . \mathrm{kg}^{-1}$. The animals were divided into 9 groups of 7 rats each. Distilled water (control group), total hydro alcoholic extract of roots of A. leiocarpus at 125, 250 and $500 \mathrm{mg} \cdot \mathrm{kg}^{-1}$; pellet fraction at 50 and $100 \mathrm{mg} \cdot \mathrm{kg}^{-1}$; supernatant fraction $(50,100$ mg.kg-1) and metformin (100 mg.kg-1) were administered by gavage 30 minutes before glucose overload. Blood glucose was measured at vein tail by glucometer Accu- Check Active (Germany) at $0,30,60,120$ and 180 minutes after substances administrations 11 .

\section{Effects of total extract of Anogeissus leiocarpus on normoglycemic mice}

Three groups of seven fasted mice were used. Group I served as a control; group II received total extract of roots of $A$. leiocarpus at a dose of $500 \mathrm{mg} \cdot \mathrm{kg}^{-1}$, and group III received metformin at a dose of $100 \mathrm{mg} \cdot \mathrm{kg}^{-1}$. Blood glucose was measured as previously.

Intestinal absorption of total extract and fractions of Anogeissus leiocarpus in rat everted gut sac model

Fiftheen Sprague Dawley rats were fasted for 24 hours with access to water. Intestine segments were inverted according to the method of Halmilton and Butt, 2013 and weighted 12 . The incubation medium was Krebs-Henseleit Bicarbonate buffer (KHB). The composition of the buffer was $(\mathrm{mM} / \mathrm{l})$ : NaHCO3 25; $\mathrm{NaCl}$ 118; $\mathrm{KCl} 4.7 ; \mathrm{MgSO} 4$ 1.2; $\mathrm{CaCl} 2$ 1.2; and Na2EDTA $9.7 \mathrm{mg} / \mathrm{L}$. After tying, the fragments were filled with $1 \mathrm{ml} \mathrm{KHB}$ solution (serosal solution), and then placed in Elenmeyer's containing $10 \mathrm{ml} \mathrm{KHB}$ (mucosal solution). The whole mixture was oxygenated and incubated at $37^{\circ} \mathrm{C}$ with continuous stirring 13 .

To study the effect of the plant extracts on the absorption of glucose, glucose at varying concentrations $(0.4,0.6,0.8$ and $1 \mathrm{mM} / 10 \mathrm{ml}$ ) was added into mucosal compartment fluid just before the beginning of the experiment. The total extract (5mg.ml-1), the supernatant and pellet fractions (1mg.ml-1) were added to the same compartment. After 60 minutes of incubation, the fragments were removed from the gut sac bath, and the serosal fluid was drained through a small incision into a test tube. Empty sacs were weighed. Glucose concentration in the serous and mucous fluids was measured using a GOD- PAP kit (method of Trinder). The standard range was made by glucose. The amount of glucose in the serosal compartment is treated as "release" and was calculated and expressed as $\mathrm{mM} / \mathrm{g}$ tissue wet weight/h.

Determination of Glucose adsorption capacity of total extract and fractions

This test was performed according to the method of 14 with some little modifications.

Briefly, samples of total extract and fractions $\left(5,10,15 \mathrm{mg} . \mathrm{ml}^{-}\right.$ 1) were added to $10 \mathrm{ml}$ of glucose solution of increasing concentrations $(5,10,20,50$ and $100 \mathrm{mM})$. The mixture was stirred well, incubated in a shaker water bath at $37^{\circ} \mathrm{C}$ for 6 hours, centrifuged at $4,000 \times \mathrm{g}$ for $20 \mathrm{~min}$. At the end of the incubation, glucose concentration was determined by using GOD PAP (method of Trinder).

The percentage of adsorption was calculated using the following formula:

$\%$ Adsorption $=\left(\mathrm{G}_{1}-\mathrm{G}_{6} / \mathrm{G}_{1}\right) * 100$

$\mathrm{G}_{1}$ : glucose concentration of original solution $\mathrm{G}_{6}$ : glucose concentration after 6 hours.

\section{Statistical analysis}

Results were expressed as mean \pm standard error of the mean (SEM). Statistical analysis was performed by two-way analysis of variance (ANOVA) followed by Dunnett's test to evaluate significant differences between groups. The level of significance was set at $\mathrm{p}<0.05$ and statistical analysis were carried out using Graph Pad Prism 7.0.

\section{RESULTS AND DISCUSSION}

\section{Results}

Effects of total extract of Anogeissus leiocarpus and fractions on oral glucose tolerance test

An increase of blood glucose was observed in mice compared to controls, after 30 minutes of the administration of glucose. Compared to the controls, the total extract of $A$. leiocarpus at the dose of 250 and $500 \mathrm{mg} . \mathrm{kg}^{-1}$, significantly reduced hyperglycemia-induced by glucose overload in mice $(\mathrm{p}<$ 0.0001 ) during one hour. The decrease of hyperglycemia was at T30, $18.63 \%$ for T.E 250, $30.89 \%$ for T.E 500; and respectively $23.18 \%, 32.58 \%$ at T60 compared to controls (figure 1A). This significant reduction of blood glucose level was confirmed by the area under the curve of the glucose tolerance which measured the total amount of available glucose in the blood compared to controls (figure 1B).

During 30 minutes, the pellet at 50 and 100 mg.kg-1 caused a significant decrease $(\mathrm{p}<0.0001)$ of the amount of glucose in blood respectively $11.79 \%$ and $27.64 \%$ compared to controls.

At the dose of $50 \mathrm{mg} \cdot \mathrm{kg}^{-1}$ of the supernatant, the reduction of glycemia occurred at T30, T60 (p< 0.0001) and T120 ( $<<$ 0.05 ); respectively $26.82 \%, 19.09 \%$ and $22.54 \%$ of reduction.

Supernatant fraction (100 mg.kg-1) significantly decreased significantly $(\mathrm{p}<0.0001)$ the blood glucose level. The percentage of reduction was at T30 (51.22\%), T60 (50.14\%), T120 (43.51\%) and T180 with $39.58 \%$ at p< 0.01 compared to controls (Figure 2A).

This significant reduction of blood glucose level was confirmed by the decrease of the area under the curve of the glucose tolerance (Figure 2B). 


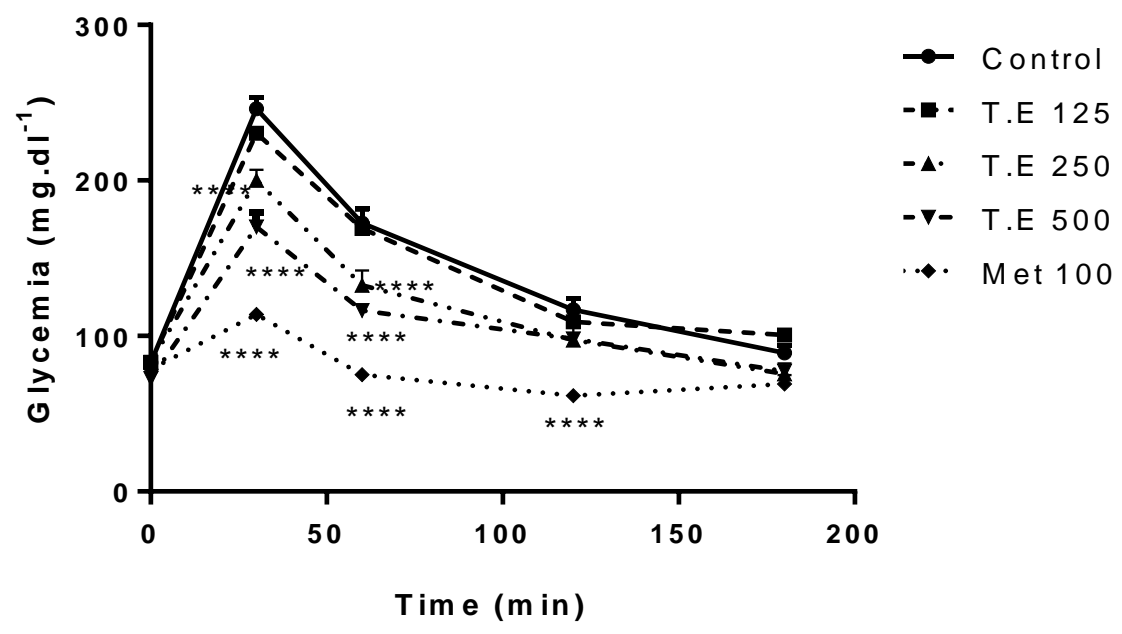

Figure 1A: Effect of total extract on hyperglycemia

Hyperglycemia was induced by administrating orally 4 g.kg-1 of glucose to fasted mice. Control: received distillated water. T.E 125, T.E 250 and T.E 500: treated respectively with 125 , 250 and 500 mg.kg- ${ }^{-1}$ of the total extract; Met: treated with metformin at 100 mg.kg-1, used as reference drug. Results were expressed as mean \pm SEM. ${ }^{* * * *} p<0.0001 ;{ }^{* * *} p<0.001$; ${ }^{* *} p<0.01 ;{ }^{*} p<0.05$ : compared to the control. $\mathrm{N}=7$

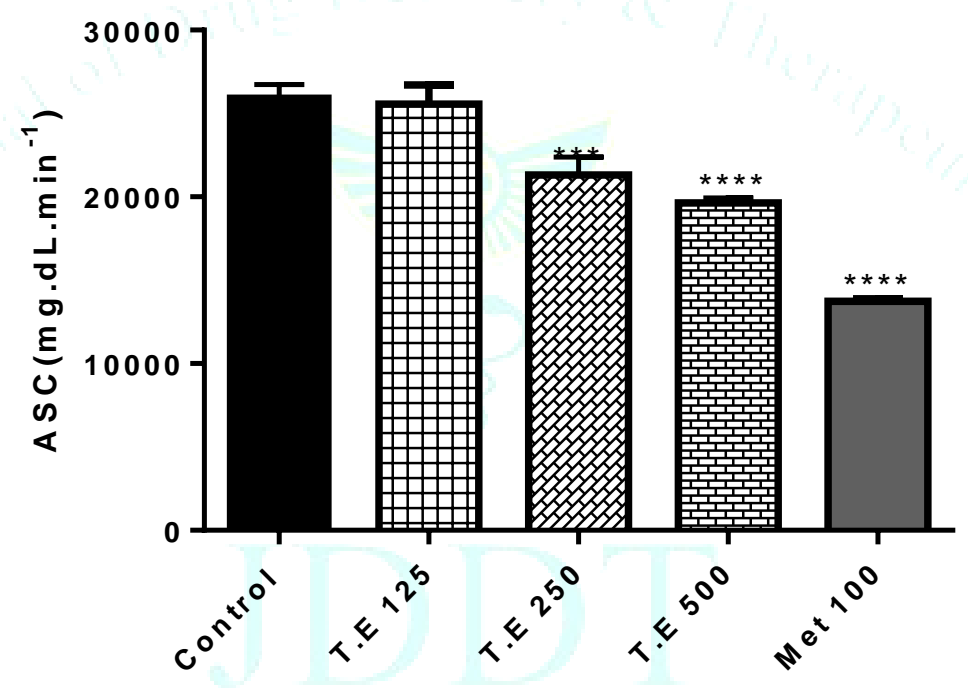

Figure 1B: Area under the curve of blood glucose

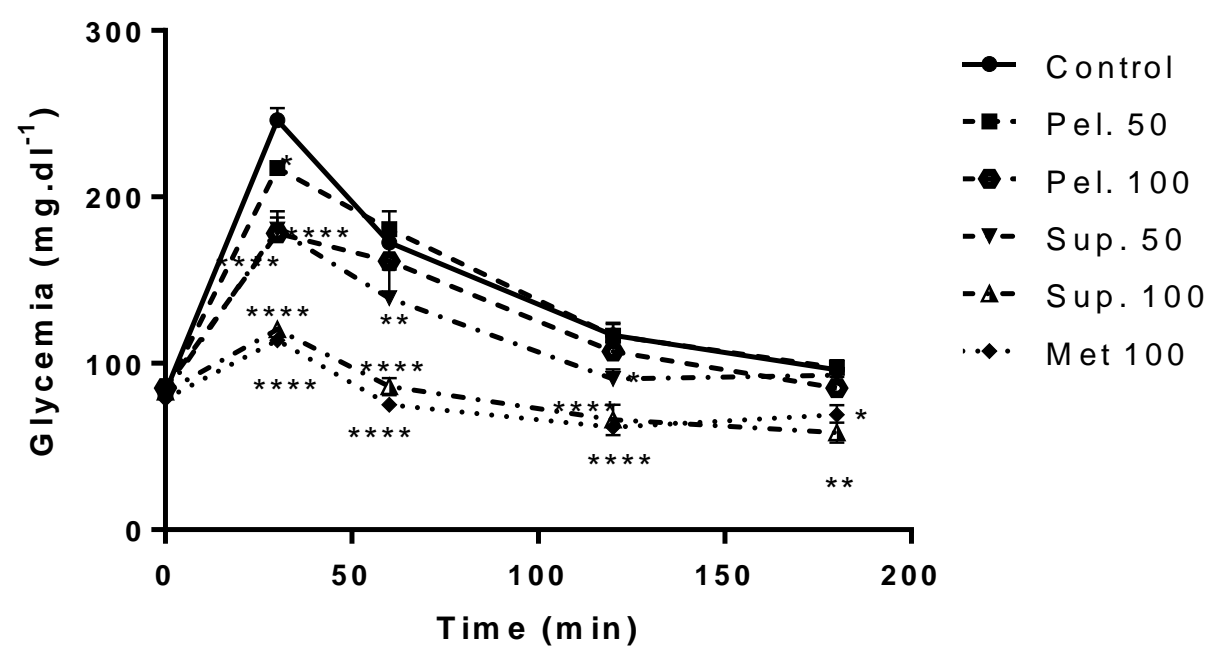

Figure 2A: Effect of fractions on hyperglycemia 
Hyperglycemia was induced by administrating orally 4 g.kg-1 of glucose to fasted mice. Control: received distillated water. Pel.50, Pel.100: respectively treated with 50 and 100 mg.kg-1 of the pellet supernatant; Sup.50, Sup.100: treated respectively with 50 and $100 \mathrm{mg} \cdot \mathrm{kg}^{-1}$ of the supernatant; Met: treated with metformin at 100 mg.kg-1, used as reference drug. Results were expressed as mean \pm SEM. ${ }^{* * * *} p<0.0001$; ${ }^{* * *} p<0.001{ }^{* *} p<0.01 ;{ }^{*} p<0.05$ : compared to the control. $\mathrm{N}=7$

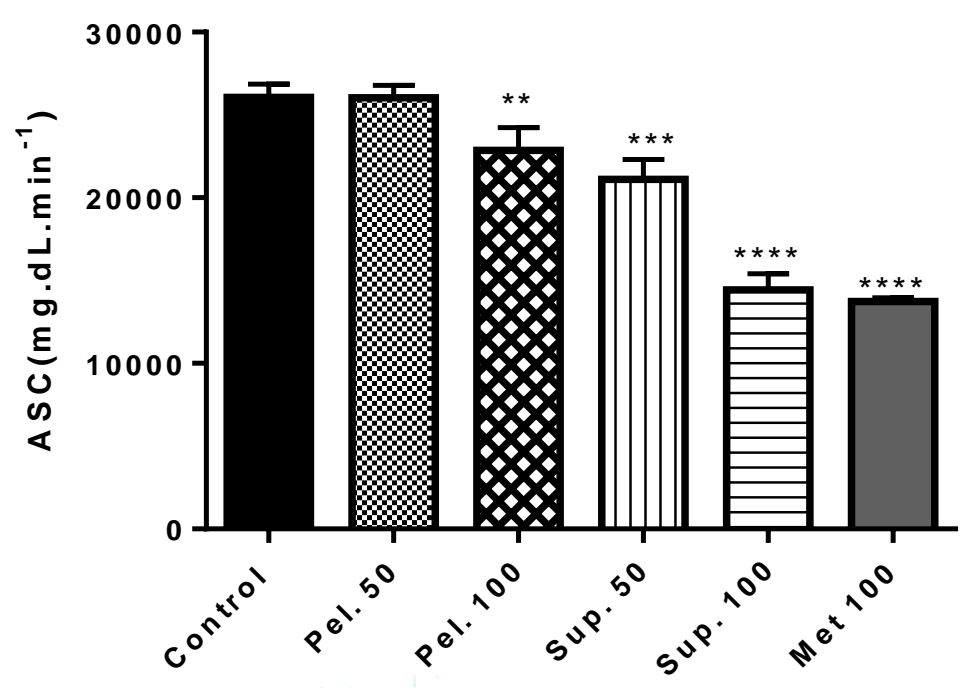

Figure 2B: Area under the curve of blood glucose

Effects of total extract of Anogeissus leiocarpus on normoglycemic mice

At the dose of $500 \mathrm{mg} \cdot \mathrm{kg}^{-1}$, hydroalcoholic extract of $A$. leiocarpus has not decreased significantly $(\mathrm{p}>0.05)$ basal glucose level in mice compared to controls. The same effect was noticed with Metformin (Figure 2A). Compared to controls, no significant reduction of basal blood glucose level was indicated by the area under the curve (Figure 2B).

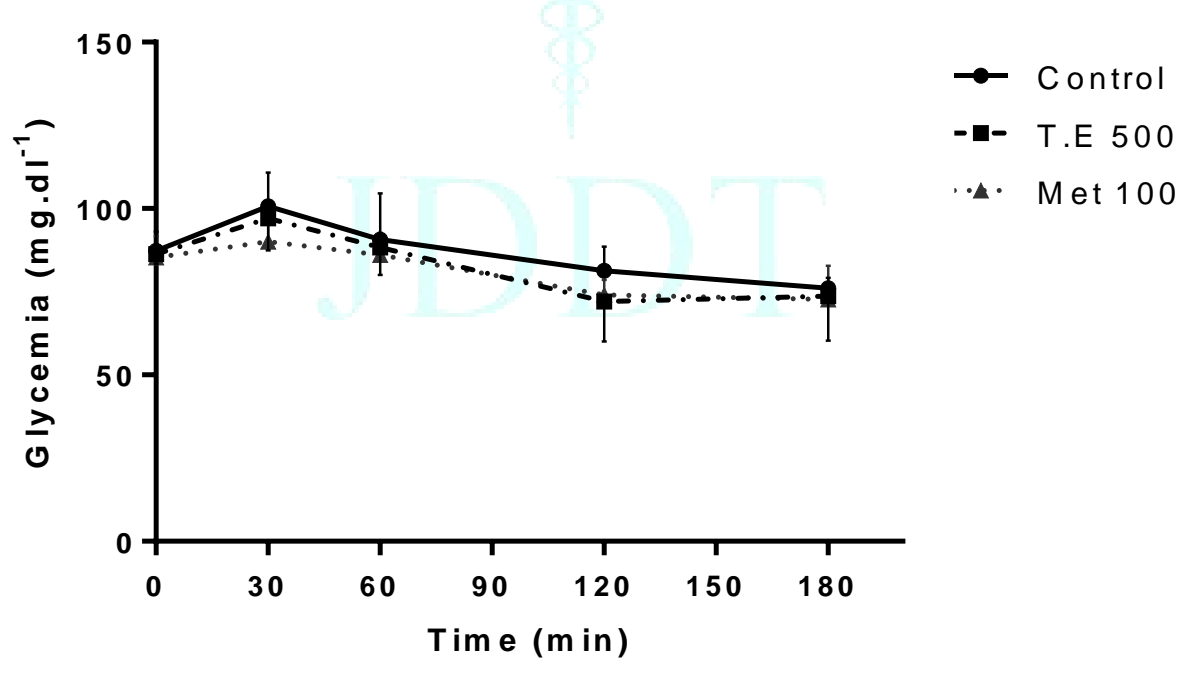

Figure 3A: effect of hydroalcoholic total extract on normoglycemic mice

After measuring basal blood glucose level, distilled water and the extract were administrated to 9 hours fasted mice. Control: received distillated water. T.E 500: treated with 500 mg.kg-1 of the extract; Met: treated with metformin at 100 mg.kg-1 ${ }^{-1}$ Results were expressed as mean \pm SEM. $N=7$. 


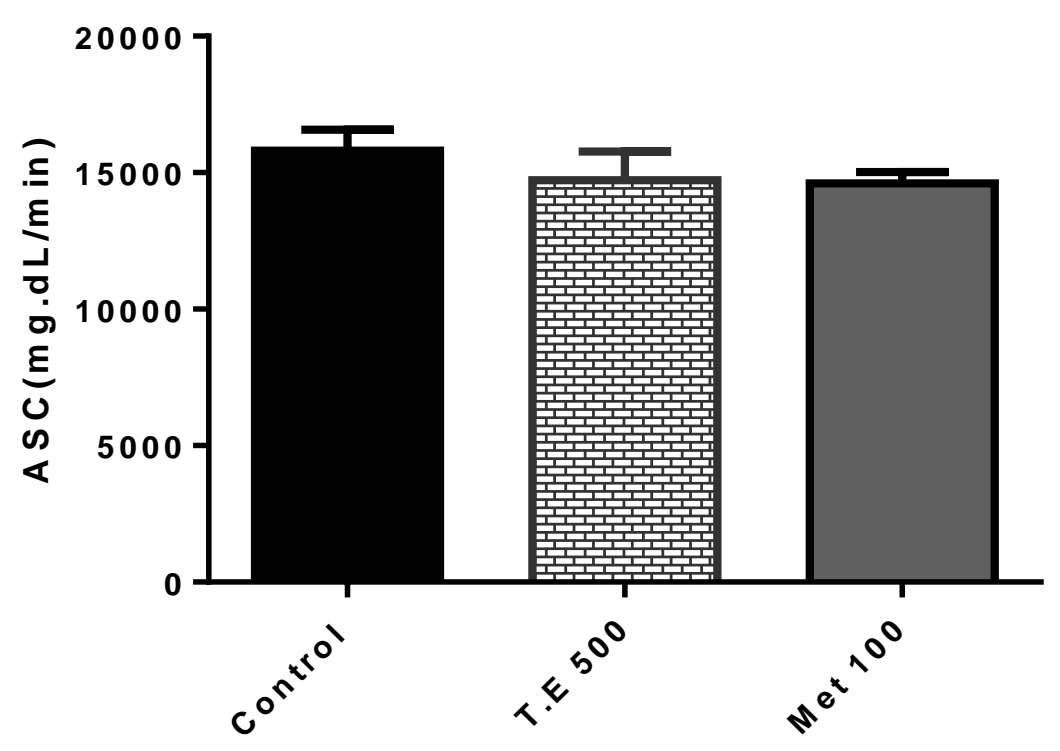

Figure 3B: Area under the curve of basal blood glucose

Effect of the total extract and fractions of Anogeissus leiocarpus on intestinal glucose absorption

In the presence of $0.6 \mathrm{mM}$ of glucose, there was a significant reduction of released glucose in the reverse intestine treated with total extract $(p<0.01)$, pellet and supernatant fraction $(p<0.001)$. This diminution was more pronounced $(p<0.001)$ in reverse intestine treated with supernatant fraction compared to controls in the presence of $1 \mathrm{mM}$ of glucose (Table 1).

Table 1: Effect of hydroalcoholic total extract and fractions of Anogeissus leiocarpus on the release of the varying concentrations of glucose by everted gut sacs

\begin{tabular}{|l|l|l|l|l|}
\hline & \multicolumn{2}{|l|}{ Released Glucose (mM.g-1 tissue wet weight.h-1) } \\
\hline $\begin{array}{l}\text { Glucose concentration } \\
(\mathrm{mM} / 10 \mathrm{ml})\end{array}$ & Control & $\begin{array}{l}\text { Total Extract } \\
\left(5 \mathrm{mg}^{-1} \mathrm{ml}^{-1}\right)\end{array}$ & Pellet $\left(1 \mathrm{mg}^{\left.-\mathrm{ml}^{-1}\right)}\right.$ & $\begin{array}{l}\text { Supernatant } \\
\left(1 \mathrm{mg} \cdot \mathrm{ml}^{-1}\right)\end{array}$ \\
\hline 0.4 & $0.23 \pm 0.01$ & $0.24 \pm 0.02$ & $0.41 \pm 0.04$ & $0.36 \pm 0.08$ \\
\hline 0.6 & $1.38 \pm 0.01$ & $0.92 \pm 0.14^{* *}$ & $0.69 \pm 0.03^{* * *}$ & $0.53 \pm 0.10^{* * *}$ \\
\hline 0.8 & $1.52 \pm 0.01$ & $1.08 \pm 0.13^{*}$ & $1.06 \pm 0.11^{* *}$ & $1.05 \pm 0.02^{* *}$ \\
\hline 1 & $1.72 \pm 0.02$ & $1.39 \pm 0.12$ & $1.35 \pm 0.18^{*}$ & $1.14 \pm 0.18^{* * *}$ \\
\hline
\end{tabular}

The fragment of the everted gut sacs were incubated in Kerbs-Henseleit Buffer at $37^{\circ} \mathrm{C}$. Values are expressed as mean $\pm \mathrm{SEM}$ of three experiments. ${ }^{*} p<0.05 ;^{* *} p<0.01 ;^{* * *} p<0.001$ vs control.

\section{Adsorption capacity of total extract and fractions of Anogeissus leiocarpus}

The total extract and fractions of A. leiocarpus adsorbed glucose in vitro. The percentage of glucose adsorption decreased as the glucose concentration increased. It varied from 27 to $79 \%$ and from 47 to $74 \%$ when the glucose concentrations were respectively 50 and $100 \mathrm{mM}$. At the glucose concentrations (50 and $100 \mathrm{mM}$ ), there was an increase in the percentage of adsorption when the concentration of extract or fractions increased (Figures 4D and $4 \mathrm{E}$ ). At $\mathrm{G}=5 \mathrm{mM}$, it should be noted that the total extract or supernatant at $5 \mathrm{mg} \cdot \mathrm{ml}^{-1}$ adsorbed $100 \%$ of the glucose (Figure 4A). The pellet adsorbed less glucose than the total extract and supernatant (Figure 4). 
A

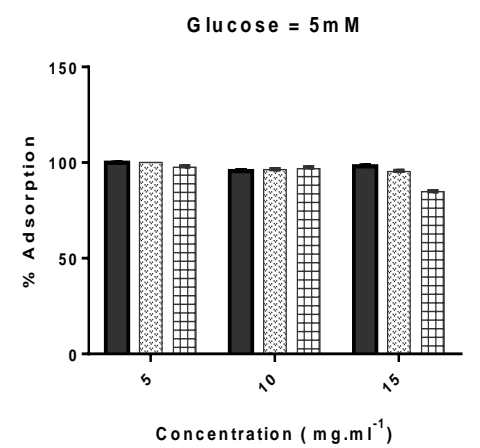

C

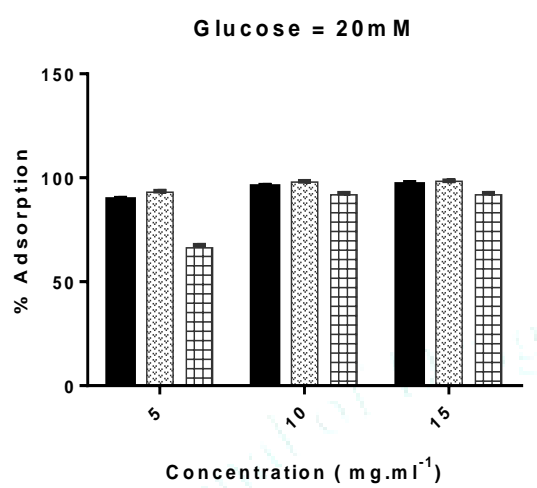

B

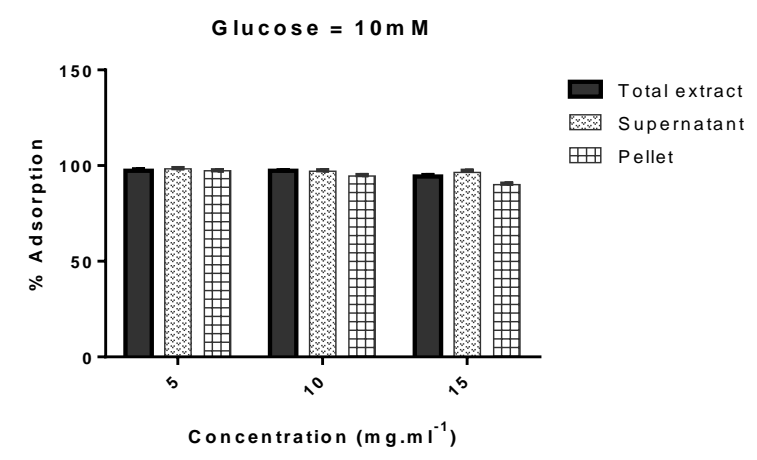

D

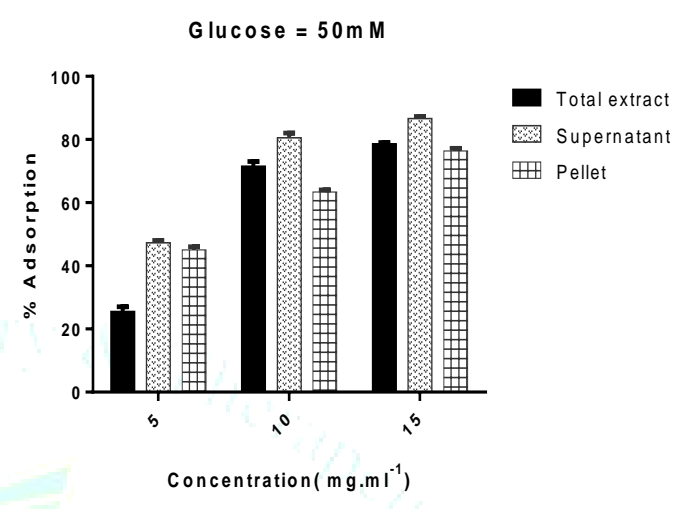

E

G Iucose $=100 \mathrm{~m} \mathrm{M}$

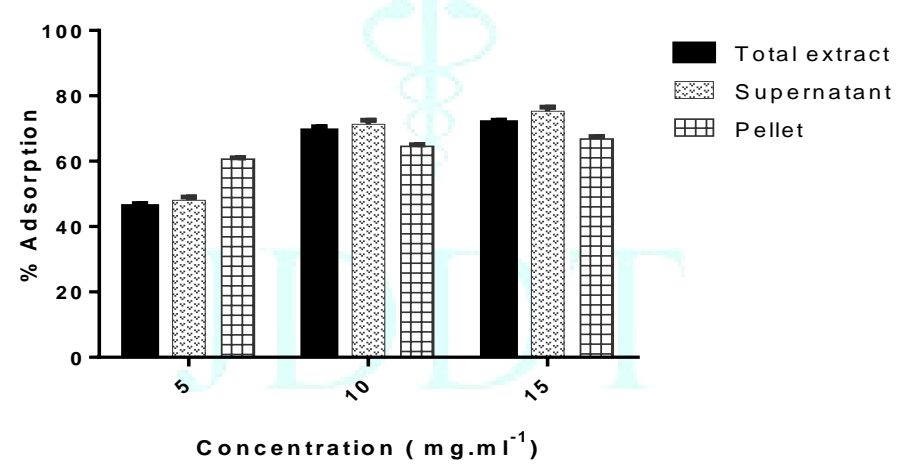

Figure 4: glucose binding capacity of hydroalcoholic total extract and fractions at different concentrations of glucose (A, B, C, D and E).

Samples of total extract and fractions $\left(5,10,15 \mathrm{mg} \cdot \mathrm{ml}^{-1}\right)$ were added to $10 \mathrm{ml}$ of glucose solution of increasing concentrations $(5,10,20,50$ and $100 \mathrm{mM})$. Each value represents mean $+\mathrm{SEM}, \mathrm{N}=3$.

\section{DISCUSSION}

Our study was undertaken in order to evaluate the hypoglycemic property of the hydroalcoholic extract and root fractions of $A$. leiocarpus.

An increase of the blood glucose level occurred when 4 g.kg-1 glucose was administrated orally to mice, with a peak at 30 minutes which returned to the basal glucose level after 120 minutes. This is due to the fact that in general circulation, glucose first raises blood glucose levels before being used for the body's needs or stored under the direct action of insulin 15 .

The hypoglycemic activity of the total extract, pellet and supernatant fractions of $A$. leiocarpus roots was evaluated in normal mice with orally induced hyperglycemia. At 30 minutes after glucose overload, the total extract and all fractions (supernatant and pellet) significantly reduced hyperglycemia dose - dependent manner compared to controls. However, the reduction of hyperglycemia was more pronounced in mice treated with the supernatant fraction at 100 mg.kg-1. This was confirmed by the aera under the curve. The same effect was noticed with the group treated with Metformin.

It is well established that metformin has a multifactorial mode of action, by improving insulin sensitivity (increasing peripheral glucose utilization) and decreasing hepatic glucose production. It also reduces the gastrointestinal absorption of glucose in people living with diabete type 216 .

In our conditions, the extract at the $500 \mathrm{mg} \cdot \mathrm{kg}^{-1}$ of the total extract in normoglycemic mice did not significantly decrease basal blood glucose levels compared to controls. As metformin, the hydroalcoholic extract of the roots of $A$ 
leiocarpus would possess an antihyperglycemic activity, suggesting an extra-pancreatic mechanism of action. On the order side, on alloxan inducing diabetic rats, Onoja et al revealed the hypoglycemic activity of the ethanolic extract of leaves of A. leiocarpus [8]. The extract may increase the use of glucose by peripheral tissues, decrease intestinal absorption of glucose or store it in the form of glycogen as metformin 17 .

Severe postprandial hyperglycaemia is avoided if intestinal glucose absorption is inhibited.

The inverted intestine test was adopted in order to reveal the effect of the plant on intestinal absorption of glucose. Glucose enters the epithelial cells following secondary active $\mathrm{Na+-}$ coupled transport via sodium-glucose co-transporters (SGLT1 and 2). It is then absorbed through the basolateral membrane into the interstitial fluid by facilitated diffusion (GLUT2) and then diffused into blood 18. Ex vivo, the significant reduction of released glucose in the reverse intestine observed, showed that the total extract and supernatant fraction reduced the glucose's absorption. This was more potent with supernatant fraction than the total extract. The extract would regulate the glucose uptake by inhibiting its absorption.

To elucidate the mechanism by which total extract and supernatant fraction inhibited the intestinal absorption of glucose, in vitro glucose adsorption test was therefore carried out.

After 6 hours of incubation, we noticed that the total extract and the fractions adsorbed glucose by binding it in vitro. Nevertheless, the supernatant fraction bound more glucose than the total extract. The results indicated that the adsorption capacities of the total extract and fractions were directly proportional to the molar concentration of glucose and higher amount of glucose was bound with the increasing of glucose concentration. This proportionality was also found by Bhutkar et al who evaluated the adsorption capacity of plants as $B$. aristate and M. pruriens ${ }^{19}$. Thereby, the extract would to slow down the intestinal absorption of glucose by binding glucose, consequently reduces the postprandial hyperglycemia.

This increasing capacity to bind glucose may be due to the phytoconstituent present in the extract.

\section{CONCLUSION}

The study has revealed the antihyperglycemic activity of the total hydroalcoolic extract, fractions of $A$. leiocarpus roots and some of its extra pancreatic activity by binding glucose and inhibited the absorption of glucose in the intestine. This justifies the traditional use of Anogeissus leiocarpus in the treatment of diabetes type 2. For the full elucidation of the mechanism of action of the plant, further studies are needed to be carried out.

\section{CONFLICTS OF INTEREST}

\section{Declared none}

\section{REFERENCES}

1. Ighodaro 0. M. Molecular pathways associated with oxidative stress in diabetes mellitus. Biomedicine \& Pharmacotherapy, 2018; 108, 656-662 https://doi.org/10.1016/j.biopha.2018.09.058

2. International Diabetes Federation (IDF). (2019). IDF diabetes atlas: $9^{\text {th }}$ edition. https://www.diabetesatlas.org/en/

3. American Diabetes Association (ADA). Approaches to glycemic treatment. Diabetes care, 2016; 39(Supplement 1):S52-S59. https://doi.org/10.2337/dc16-S010

4. Turner N., Zeng X.Y., Osborne B., Rogers S., Ye J-M. Repurposing drugs to target the diabetes epidemic. Trends in Pharmacological Sciences, 2016; 1308:1-11.doi: 10.1016/j.tips.2016.01.007.

5. Mann A., Amupitan J. O., Oyewale A. O., Okogun J. I., Ibrahim K. Antibacterial activity of terpenoidal fractions from Anogeissus leiocarpus and Terminalia avicennioides against community acquired infections. African Journal of Pharmacy and Pharmacology, 2009; 3(1):022-025.

https://www.researchgate.net/publication/228651943

6. Atawodi S. E., Adekunle O. O., Bala I. Antioxidant, organ protective and ameliorative properties of methanol extract of Anogeissus leiocarpus stem bark against carbon tetrachlorideinduced liver injury. International Journal of Pharmaceutical Sciences and Research, 2011; 2(6):1443.

http://dx.doi.org/10.13040/IJPSR.0975-8232.2(6).1443-48

7. Salau A. K., Yakubu M. T., Oladiji A. T. Cytotoxic activity of aqueous extracts of Anogeissus leiocarpus and Terminalia avicennioides root barks against Ehrlich ascites carcinoma cells. Indian journal of pharmacology, 2013; 45(4):381. doi: 10.4103/0253-7613.115023.

8. Onoja U. S., Ugwu C. C., Uzor P. F., Nweze I. E., Omeje E. O., Nnamani P. O., Effiong E. J. Effect of Anogeissus leiocarpus Guill and Perr Leaf on Hyperglycaemia and Associated Dyslipidaemia in Alloxan-induced Diabetic Rats. Dhaka University Journal of Pharmaceutical Sciences, 2018; 17(1):6572. https://doi.org/10.3329/dujps.v17i1.37120

9. Kpodar M. S., Lawson-Evi P., Bakoma B., Eklu-Gadegbeku K., Agbonon A., Aklikokou, K., Gbeassor, M. Ethnopharmacological survey of plants used in the treatment of diabetes mellitus in south of Togo (Maritime Region). Journal of Herbal Medicine, 2015; 5(3):147-152. https://doi.org/10.1016/j.hermed.2015.06.002

10. Zoua K., Batomayena B., Kossi M., Lawson-Evi P., Kwashie E. G., Kodjo A., \& Messanvi G. Effects of plumeria alba roots hydro alcoholic extract on some parameters of type 2 diabetes. Res. J. Med. Plant, 2014 ; 8 :140-148. Doi: 10.3923/rjmp.2014.140.148

11. Lawson-evi P., Bakoma B., Titrikou H., Eklu-Gadegbeku K., Aklikokou K., Gbeassor M. Phytochemical screening, antioxidant and hypoglycemic activity of Coccoloba uvifera leaves and Waltheria indica roots extracts. International Journal of Pharmacy and Pharmaceutical Science, 2015; 7 (5):279-283.

https://innovareacademics.org/journals/index.php/ijpps/arti cle/view/5523.

12. Hamilton K. L., and Butt A. G. Glucose transport into everted sacs of the small intestine of mice. Advances in physiology education, 2013; 37(4):415-426. doi: 10.1152/advan.00017.2013.

13. Therasa S. V., Thirumalai T., Tamilselvan N., David E. In-vivo and ex-vivo inhibition of intestinal glucose uptake: a scope for antihyperglycemia. Journal of Acute Disease, 2014; 3(1):36-40. DOI: $10.1016 / \mathrm{s} 2221-6189(14) 60008-1$

14. Ou S., Kwok K. C., Li Y., Fu L. In vitro study of possible role of dietary fiber in lowering postprandial serum glucose. Journal of agricultural and food chemistry, 2001; 49(2):1026-1029. DOI:10.1021/jf000574n

15. Chang L., Chiang S. H., Saltiel A. R. Insulin signaling and the regulation of glucose transport. Molecular medicine, 2004; 10(7-12):65-71. doi: 10.2119/2005-00029.

16. Wu T., Xie C., Wu H., Jones K. L., Horowitz M., Rayner C. K. Metformin reduces the rate of small intestinal glucose absorption in type 2 diabetes. Diabetes, Obesity and Metabolism, 2017; 19(2):290-293. https://doi.org/10.1111/dom.12812

17. Sakar Y., Meddah B., Faouzi M. Y. A., Cherrach Y., Bado A., Ducroc R. Metformin-induced regulation of the intestinal Dglucose transporters. Journal of physiology and pharmacology, 2010; 61(3):301.

18. Navale A. M., Paranjape A. N. Glucose transporters: physiological and pathological roles. Biophysical reviews, 2016; 8(1):5-9. https://doi.org/10.1007/s12551-015-0186-2

19. Bhutkar M., Bhinge S., Randive D., Wadkar G., Todkar S. Studies on Glucose Adsorption Capacity of Some Indigenous Plants. Global Journal of Pharmacy and Pharmaceutical Sciences 2018; (5)1. DOI: 10.19080/GJPPS.2018.05.555651 